\title{
Possessions Ceded for the Benefit of the Hospitals and Churches From the Sighisoara County
}

\author{
Mariana Borcoman \\ Transylvania University of Brasov, Brasov, Romania
}

\begin{abstract}
Transilvania is a province of the actual state of Romania, geographically situated in the middle of the country, in the inner arch of the Carpathians. Starting with the 10th century, the territory of Transilvania became attractive for the neighboring Hungarian royalty and later on, in the 11th century it was annexed into Hungary. For a better control of the newly annexed territory and in order to convert the orthodox population to Catholicism, the Hungarian rulers brought the Szeklers to Transilvania and two centuries later, German originating populations, from Rhine, Luxemburg, and Saxony (the name of Sas people, or Saxon of Transilvania derives from "Saxony"). The aim of this paper is to focus on the Sighisoara County, namely on the easement of certain areas for temporary or permanent maintenance or use by the church and hospitals in the region. That was a common practice in Medieval Europe aimed at ensuring the survival means for these institutions. However, it was not the only one to serve this goal. There were also donations on behalf of various people or allocations of money by the county authorities. The documents attesting this are unpublished, unedited and are to be found in the archives of the Brasov County, Budapest, and Vienna. They are the stepping stone of this paper and hence, they grant its originality. The objectives of the paper are to bring arguments in favor of the thesis that community money was directed towards meeting the needs of the hospitals, as well as towards supporting the widows, the orphans, and the needy ones. Worth noting in this respect is the management of the funds ceded to the church and county hospitals and that actually benefitted the whole community. Moreover, the paper also emphasizes the role played by education, since the latter is an important landmark for a community's development level.
\end{abstract}

Keywords: county, craft, "dica" tax, possessions, great landed property, magistrate, bestowed properties

\section{The History of the Sighisoara Fortress and County}

\section{Historical Attestation of the Fortress}

According to existent data, the Saxon fortress, situated above the banks of the Tarnava River, was erected after the Mongolian invasion, which was said to have caused substantial damage, toward the end of the 13th century. Before its construction, the site had been occupied by an older settlement and the territory was organized by the Hungarian royalty like a county, where, later on there will be the Saxon county.

The name of the place "Sighisoara" raised a lot of interest and it was analyzed within the "Saxon Transilvanian Dictionary" by Wollf (1889) who considered that "The site was first mentioned by documents in

Mariana Borcoman, lecturer, Departament Sociology and Cumunication, University Transsylvania of Brasov. 
1280, under the name 'Castrum Sex', then, in 1349, its name had become Castru Sches, in 1429-Schespurch" (pp. 34-35). At the same time, it is considered that “... the name comes from Hungarian, seges, meaning 'fortress', and in documents it appears as Seguswar" (Kisch, 1924, pp. 152-153). The Romanian name of the fortress comes from the Hungarian toponym Segeswar, in German "Schägesburg" and "the Latin version Castrum Sex appears for the first time written in a document dating in 1320" (Nussbächer, 1994, p. 138), therefore, it will be later on mentioned in documents of the Saxon counties as Castroschez (1402), Castroschesch (1423), "There is no mentioning related to a specific order in which the name is used (among theTtransilvanian fortresses), but it may have been a mere organization of the territory, probably connected with the role detained by the representative of the county" (Nussbächer, 1994, p. 138). The name of the place referred to the upper part of the town and the "Romanian term Schegischone was for the first time used by Vlad Dracul, the voivode of Principality of Wallachia, in a document dated July 1, 1435" (Kroner, 1998, p. 77), and "The fortress to which Sighisoara owes its name used to be one of the border fortresses of the Hungarian empire, built with the purpose of consolidating the Hungarian empire in Transilvania, after the year of 1000, when the extreme southern border of Hungary was the linia drawn by Tarnava Mare River" (Horedt, 1958, p. 119).

The oldest documentary attestation of Sighisoara is dated in 1298, “. $\ldots$ at the time when a papal letter was sent from Rome, as a privilege for St. Mary's Church from Sighisoara” (Nussbächer, 1985, p. 98).

In the beginning a traders' place evolved into an important town, situated on Tarnava valley, close to Şaeşului valley and later on "in 1337, the county of Sighisoara, having the administrative center in Sighisoara was mentioned" (Zimmermann, 1990, p. 490) (next to other counties such as Sibiu, Medias, and Rupea) and it became an important center for crafts activity coordination. These crafts represented associations of craftsmen grouped into trades and documents prove that in Sighisoara "there were 10 crafts, apart from which there were many craftsmen who were not included in any crafts... as compared with Cluj ans Sibiu, each with 11 crafts, and Brasov, with 9 crafts" (Nussbächer, 1967, p. 5). The crafts used to stand against anyone who would practice their trades illegally, and therefore, crafts enjoyed protection from University and privileges from Wallachian rulers. We can notice the important role played by crafts within the fortress, accordingly crafts would receive their own tower, from the fortress' fortified walls, to be administered, while the richest people used to hold administrative positions (such as minor ruler or mayor).

Sighisoara lies at $350 \mathrm{~m}$ high above the sea level and due to this reason Tarnava River has so many tributaries. The hills around the town, on each side of Tarnava River, are up to $150 \mathrm{~m}$ high and they are terraced. South of the town there are two tributaries of Tarnava River flowing: Valea Şaeşului and the small creek Valea Câinelui. These two streams divide the town into three sectors: (1) the Fir-Tree Forest/Romanian "Pădurea de brad" (< germ. "Gelben Burg”) Băii street, 692m high; (2) "Galtenburg”, nowadays the Central part (Post Office); and (3) the Upper Plateau/Romanian "Platoul de sus", the highest region.

\section{Demographic Data}

The number of people in town was important and relevant for taxation. In the town, there was a tax named "dica" (1, 2 gold coins), representing small taxation units per neighborhoods and according to which we can deduce the number of inhabitants. In the county, a system of 10 units "Zahlzins" was imposed. The population of Sighisoara, following the census of 1,489, included 600 households, 20 aliens (without a house), three 
administrative representatives of the town, two millers, nine poor people, and four shepherds. Based on taxation methods of 1589, there resulted that "there were 848 tax-paying people, amounting up to 590.50 dica tax" (Gräef, 1998, p. 60). In 1631, Sighisoara numbered 2,115 inhabitants and, due to the plague, there were uninhabited households. In 1700, there were 5,579 people; in 1851, there were 7,206 people; and in 1893, there were 9,629 people, out of whom $54.45 \%$ were Saxons, $25.40 \%$ were Romanians, $16.38 \%$ were Hungarians, and $3.77 \%$ were of other ethnicity. In the 20th century, records show a decrease of the Saxon population due to deportations to Russia and to emigrations to Germany.

\section{Schools}

Apart from the church, the school played an important role for the community of Sighisoara (and even for the neighbouring villages of the county, since they sent school attendants there). A well-organized education must have been established soon after the Saxon settlement. Yet, written evidence appears later (the 14th century), “... only in 1522” (Nussbächer, 1985, p. 60); nevertheless, there must have existed a good school in Sighisoara for some of the students to be able to be accepted by European universities. This particular school was placed near the church up the hill. The first student graduating from this school and being recorded by the University of Vienna was in 1402, Nicolaus de Castroschez, whereas, in Kracow, in 1465, there was another student, Petrus Benedicti. The titles granted by these universities included "baccauleus" and "magister artium", and they could lead to obtaining better paid jobs abroad or, to becoming administrative clerks, back home. There are historical records in this respect, dating from the fifteenth century, "Johanes Polner... secretary of Queen Mary of Hunagry; Marcus Polner, Doctor in Roman Law and priest in Şaeş; ... Nicolaus Pictoris, Doctor în Free Arts and Notary of Braşov, Ambrozius Rustici, graduate with Bacalaureus atrium, a senator then mayor" (Nussbächer, 1994, p. 128).

We can also track the school evolution for the next century; for example, we are informed by documents of 1522 that school principals were paid by the community, that "the school in Sighisoara detained an egal status with the school established by Honterus, in Brasov" (Nussbächer, 1994, p. 145) and that pupils in Sighisoara attended the superior level of the high school in Brasov to become notaries and rectors in Sighisoara. In this respect, it is remarkable the case of Laurențiu Kursch, graduate of Honterus high school, who continued his studies in Wittemberg, and then returned to become a minister in Sighisoara, and, between 1583 and 1595, a priest in Criț, and who drew up the oldest rural school regulation from Transilvania (Nussbächer, 1994, p. 147). Students who could not afford school fees, but were eager to learn, were granted stipends (study allowances), which were recorded within the town's expenses. Much later, in the 18th century, a girl-school was built and in 1784, a Romanian school was established in Sighisoara. The role detained by the church inside the community denoted an economic power, able to sustain such institutions.

\section{Hospitals}

Hospitals provided services for both the town's people and for the administrative representatives. In Sighisoara, there were two such institutions: One hospital affiliated to St. Anthony church, managed by a rector and by the priest, both elected by the town's magistrate whose authority had been empowered by Matei Corvin, in 1487, "... while from the text of the document we can deduce that the hospital had been in place since 1461 " (Nussbächer, 1981, p. 97). The site of the hospital was outside the walls of the fortress. The second hospital was destined to lepers, in the opposite side of the town, attested ever since 1507. Both hospitals benefited from some 
allowances given by the magistrate and by the Transilvanian leaders (September 21, 1549- the magistrate confirmed the donation of a pond to the hospitals in Sighisoara, from an inhabitant from Noiştat, Cincu county, situated in the "deserted" land of Țelina).

In exchange for such donations, the magistrate promised the inhabitants of Noiştat, whose property was rather small, to allow them to graze their horses in the "deserted" land (DJAN Bv A.M.O.S., 1773); on May 2, 1575, Ştefan Bathory, Transilvania's ruler was notifying Ladislau Sombori, the tenant of the ruler's "decimal" taxes, that he had bestowed St. Anthony Hospital and St. Spirit Hospital the entire "decimal" tax value and the incomes of the "deserted lands" to the town and county of Sighisoara, bordered by Retiş, Moha, Daia, Bărcut, Meşindorf, and Hendorf villages and thus he interdicted Sighisoara people's prevention from collecting other taxes and has decided upon the free use of the resulting money (DJAN Bv A.M.O.S., 1782, pp. 1-2).

In the city there was a public bath, attested from 1511. It was placed in the middle of the town on the street named "Bath". The bath administrator, also nicknamed "bath craftman" is mentioned in "... the towns records of 1522 , as a person coming from Mediaş and who was granted a loan for moving and settling in Sighisoara" (Teutsch, 1853, p. 161). Plague outbreaks were so common in the Middle Ages, and the did not spare the town of Sighisoara. There were mentioning in this respect, reported by chronicler Kraus, for the seventeenth century: in 1603, a time when 2,000 people got killed from the disease; in 1663 and in 1664, when the very wife of the chronicler died, too: “... in Sighisoara, 4676 souls passed away, from June to December, especially the men who had been the wisest and the most reliable" (Kraus, 1879, p. 15).

\section{Ecclesiastic Organization: The Churches}

The oldest ecclesiastic construction is the church of the Dominican Monastery, erected at the beginning of the 13th century, in Roman style (which makes it the first attested church). The inside of the church is special, it consists of lecterns "... old ever since the fourteenth century and some fresco remains, displayed all over the church, both in the choir and on the nave ceilings" (Oprescu, 1957, p. 189), the altars are also made of painted wood. The old building of the monastery was demolished in 1886 .

The church on the hill was erected in the fourteenth century. Together with the Black Church from Brasov, the Evangelic Parish Church from Sibiu and the one from Bistrita, these churches belong to an architectural style created by local craftsmen. Displaying Gothic elements in its construction, the church holds a strategic position in relation with the space around it, it being situated on the highest point of the fortress. Ever since its construction, this church benefited from numerous donations from noble men of the neighborhood (Mărghindeal, Vulcan). In the 15th century, the priest's house was built, during the mandate of Mayor Michael Polnar. Both these two buildings house organs, which are still in use nowadays.

Apart from the two churches of the upper part of the town, in the lower part there was a church belonging to the hospital (dated in the 15th century) dedicated to St. Anthony and another one dedicated to St. Nicholas (this church was bestowed with the commodities of Vulcan village of Sighisoara county). In the 15th century, a priest's house was built, “... during the mandate of Mayor Michael Polnar, from 1483 until 1491” (F. Müller, 1853, p. 330). On the banks of Tarnava River was the leper hospital, where, “. $\ldots$ in the sixteenth century a church was built" (Schuller, 1934, p. 38). Churches benefited from donations: Such as the one confirmed by Ioan Zapolya, prince of Transilvania, which consisted of 2 silver coins yearly, destined to the monastery of St. 
Dominic Order from Sighisoara, dedicated to Virgin Mary, a church built by Vladislav II in 1501 and that benefited from two extra silver coins donation (DJAN Bv A.O.S., 1750, p. 1).

The spiritual superior organization of Saxons was structured into units named deaneries or capitulums, organized as such ever since their colonization time. They were led by a dean, named by the bishop and by an archdeacon and ever since "1281-1370, the records regarding the papal taxation in Hungary mentioned the deaneries" (G. Müller, 1934, p. 40). The structure of the capitulum was not identical with the one of the county's administration or the district's; they were more numerous, namely 24-for the royal land (as compared to nine Saxon counties and two districts existing in Transilvania). The Saxons had to pay a yearly tax to the Catholic church and another one to the Evangelic church, Kathedralzins tax and the dates for paying these taxes were on St. Nicholas' day and on St. George's day.

On the territory of Sighisoara county, there were two capitulums: Saschiz and Laslea, and only several villages belonged to the Băgagiu capitulum, from "two counties". Saschiz capitulum included the villages Archita, Buneşti, Daneş, Viscri, Drăuşeni, Brădeni, Saschiz, Cloaşterf, Beia, Meşindorf, Noul Săsesc, Roadeş, Saeş, Sighisoara, Fişer, Jimbor, Apold, and Valeni (so, there were also villages belonging to neighboring counties-Rupea, Cincu, and of the county of Alba Superioară). Part of the capitulum's archives was destroyed, but there are still preserved documents in the archives from Brasov and in the archives belonging to the consistorium in Cluj.

Laslea capitulum included villages Nadeş, Laslea, and others from Alba county. The two capitulums were neighboring Medias capitulum to the Northwest, Cincu capitulum to the Southwest, Țara Bârsei capitulum to the Southwest and Cincu-Kozd capitulum to the South. Associated capitulums formed "dioceses" (G. Müller, 1934, p. 106). The activity of the capitulums' deans consisted of numerous tasks: They were in charge with visiting villages, held the right to hire and revoke priests, and they had to collect the taxes for the church.

\section{Possessions Bestowed}

\section{Vulcan-Property of St. Nicholas Church From Sighisoara}

The village situated at the border of Sighisoara county, on the territory of Alba county, was for a long time disputed by the two administrative structures. Apparently, properties coexisted in parallel: part of the village belonged to Sighisoara county and another part of it used to be a nobleman's possession. The village lies South of Sighisoara, close to Apold village. Another village, by the same name existed also in Țara Bârsei.

The documentary attestation of the village was "in 1315, by a document confirmed by King Carol Robert, a document showing that Vulcan was bought by Count Blavus, son of Arnold" (Nussbächer, 1991, p. 6), as his own property. Count Blavus transmits his legacy to his sons Martin and Nicolaus. At the end of the century, in 1396, Counts of Archita, Brădeni, and Retiş, who had possessions in the village, sold them to the town of Sighisoara, the document being confirmed by the Town Hall administration and later on this estate was ceded to the church. Part of the village remained in noblemen's possession.

The right of property in the village remains debatable, while in "1391, the ruler of Transilvania, Ladislau of Losoncz, gives one half of Vulcan village to Count Petrus of Vulcan" (Nussbächer, 1992, p. 4). The church's assets grow larger in 1438 and by a donation from "... Katharina, widowed to Egidius Parvus, citizen of Sighisoara, who had ceded his property in Vulcan, including 19 houses" (Nussbächer, 1992, p. 4). The church 
stipulated its subordinates' duties to pay the St. Martin tax to the church, to participate at erecting buildings, these people being free individuals of the county, although the village had been bought from Count Johannes of Mărghindeal in 1444.

King Matei Corvin of Hungary ceded the village to the county of Sighisoara in 1487; therefore, we find it mentioned by the census of 1488, including 32 households, and one century later, in 1531, voivode Ioan Zapolya confirmed the fact that Vulcan belonged to Sighisoara, while “... in 1590, Sigismund Bathory, ruler of Transilvania, ceded the village to St. Nicholas church from Sighisoara" (Fabinni, 1998, p. 813). Starting with 1629, Gabriel Bethlen, prince of Transilvania, on request from Martin Vassas, the mayor of Sighisoara town, agreed with the document of December 19, 1521, issued by Ludovic II, with regard to the exclusion of Vulcan village from Alba county and its inclusion into Sighisoara county (DJAN Bv A.M.O.S., 1782, pp. 15-19). Consequently, we can affirm that the situation of the village was rather sensitive, and it seemed that the church benefited from this estate until the nineteenth century.

\section{Properties Belonging to Hospitals in Sighisoara}

Michael the Brave. Situated at $7 \mathrm{~km}$ away from Saschiz, close to the village of Criț, Mihai Viteazu village used to be a nobleman's property and, similarly with Vulcan's history, part of this village remained under the administration of Alba county. In “... 1383, Salomon, son of Michael of Sighişoara, owns the Zoltan estate and in 1446, Michael Salamonis of Nadeş donates part of his property to the hospital” (Fabinni, 1998, p. 837). Data regarding this village remain very unclear, the hospital did not benefit from this property for long, because, in 1669 , the village is abandoned and part of its inhabitants go to Roadeş. We cannot say which the reasons for abandoning this place were, neither the magistrate's protocols nor the town's records kept track of this village.

Prediul Wosling (T,elina). This village finds itself in the same unclear situation just as Mihai Viteazu village. It used to be a commonly used area among the villages of the county: Retiş, Grânari, Bărcut, Daia, Meşindorf, and Brădeni. Taxes coming from these communities had been donated “... in 1575, by Ştefan Bathory, the prince of Transilvania, to Sancti Spiriti Hospital (the leper hospital) and to Brati Antony (St. Anthony's) Hospital" (F. Müller, 1885, 1886, pp. 61-62). In Sighisoara's archives, there are some documents related to this territory.

On December 14, 1614, at Alba Iulia, Gabriel Bethlen, prince of Translvania, decided that serfs who had fled from various parts of Transilvania to "Telina deserted land", which belonged to Sighisoara town, to be taken back to their previous masters, while people of Sighisoara held the right to colonize, on this territory, people from the overpopulated regions of Transilvania, people whom they might keep under control so that they did not cause any trouble to their neighbors (DJAN Bv, Miscellaneous documents, 1862).

Another document of April 29, 1621, issued at Alba Iulia by Ştefanus Bethlen of Iktar, the prince's deputy, on requested by Sighisoara's magistrate, forbade authorities of Alba county to tax those three or four households situated in the territory named "Telina deserted land", because it was on royal land and it had never paid taxes under the authority of Alba county, as results from the research undergone by some Kemeny Boldisar (DJAN Bv, Miscellaneous documents, 1862).

On September 3, 1621, the magistrate of Sighisoara town demanded of Gabriel Bethlen, the prince of Transilvania, to order his tax collectors to tax the communities of Prod, Seleuşul Mare, Daneş şi Laslea, 
following the old custom of using the county's men, but not to tax them for the previous years, since they had been very poor. With regard to the "deserted land", the magistrate required of it not to be included in taxation listed because their incomes had been donated by Ştefan Bathory to the two hospitals in Sighisoara. The magistrate also demanded that the prince allows the settlement of some people coming from Moldova in that particular place (DJAN Bv A.O.S., 1750).

Still in 1621, probably in September, the magistrate of Sighisoara town demanded of the prince of Transilvania, Gabriel Bethlen, to forbid traders of Alba county to request a tax and not to trouble those 12 Romanians who grazed the cattle of Sighisoara people in the "deserted land", because this territory was a royal land. Endorsed on the document was the resolution with regard to taxes (DJAN Bv A.O.S., 1750). It was certain, though, that this territory was under the authority of Sighisoara town and the only the town's authorities decided who could live on their lands. Concerning a possible settlement of some colonists from Moldova, documents did not mention anything else.

\section{Conclusions}

Sighisoara county, established as early as the 14th century, represented a bordering area of the royal land until the 19th century. Through its structure, and due to the fact that it managed to keep under its control many villages, the county represented an organization form specific to mediaeval times.

The unity of the county and its good organization owe to the hierarchy of clerks and to community structures existent in villages. The administrative representative of the county, Sighisoara fortress, witnessed numerous historical events and political changes in the Principality of Transilvania between the sixteenth century and the seventeenth century (in Sighisoara there were many legislative gatherings, the villages around the fortress hosted armed troops and witnessed many of the Turkish plunders).

The historical sources that remind us of this epoch come in great numbers: from documents mentioning the establishing of crafts or certifying some older ones, to donations by Transilvanian rulers to churches or tax exemption; from various decisions made by the magistrate, preserving their interesting aspect due to their mentioning everyday lifestyles and economic-administrative organization, to protocols signed between neighboring villages; and from mayors' and notaries' notes, to issues regarding the well functioning of schools. All of these, together, may offer us the picture of a well-organized administrative structure that continues to exist and carries on its old tradition.

\section{References}

DJAN Bv (Romanian State Archives, Brasov County Directorate) A.M.O.S. (Archive of the Sighisoara Magistrate). (1792). No. annex 8, pp. 1-2; annex No. 7, pp. 15-19. Brasov County Directorate for State Archives of Brasov-Documents Issued by Sighisoara's Magistrate.

DJAN Bv A.O.S. (Archive of the Sighisoara Town). (1750). No. 192 and No. 592a, p. 11. Romanian State Archives, Brasov County Directorate-Documents from Sighisoara Town's Archives.

DJAN Bv. (1862). Miscellaneous documents-Sighisoara-Țelina Court Trial, file 1862, annex Dși annex E, p. 1.

Fabinni, H. (1998). Atlas der siebenbürghisch-sächsische Kirchenburgen und Dorfkirchen, Band I (p. 813). Hermmanstadt: Monumenta Verlag.

Gräef, E. (1998). Schäßburg. Munchen: Reuterburg Verlag (Printer in Germany).

Horedt, K. (1958). Contribuții la istoria Transilvaniei sec. IV-XIII. București: Editura Academiei RPR.

Kisch, G. (1924). Erloschene Magyarentum im Siebenbürher Sachsenlande. Archiv des Vereins (Neue Foge). Kronstadt. 
Kraus, G. (1879). Schaessburger chronik. Archiv des Vereins (Neue Foge). Kronstadt.

Kroner, M. (1998). Schäßurg. Rastenburg: Printer in Germnay.

Letz, E. (1998). Schäßurg. Rastenburg: Printer in Germany.

Müller, F. (1853). Die Schäßurger Bergkirche (p. 330). Archiv des Vereins (Neue Foge). Kronstadt.

Müller, F. (1885, 1886). Geschichte der siebenbürghischen Hospitälen bis zum Jahre 1625 (pp. 61-62). Program des evanghelischen Gymnasien in Schäßburg. Viena.

Müller, G. (1934). Die Deutschen Landkapitel in Siebenbürgen und ihre Dechanten (1192-1848). Hermmmanstadt: Krafft und Drottlef.

Nussbächer, G. (1967). Scurtă schiță a istoriei administrative a scaunului Sighişoara până la 1700. Brașov: Manuscris Aflat la Arhivele Statului.

Nussbächer, G. (1981). Din trecutul medical al Sighișoarei. Trecut și viitor în medicină. București: Editura Medicală.

Nussbächer, G. (1985). Aus urkunden und chroniken (p. 98). Brasov: Editura Aldus.

Nussbächer, G. (1991, December 18). Wolkendorf bei Schäßurg im 14. Jahrhundert. Neuer Weg, p. 6.

Nussbächer, G. (1992, January 25). Wolkendorf bei Schäßurg im 15. Jahrhundert. Neuer Weg, p. 4.

Nussbächer, G. (1994). Aus Urkunden und chroniken. Brașov: Editura aldus.

Oprescu, G. (1957). Bisericile cetăţi ale saşilor în Ardeal. București: Editura Academiei.

Schuller, R. (1934). Alt Schäßurg, Herausgegeben von Verlag I. Sighisoara: Horedth.

Teutsch G. D. (1853). Die Schäßurger Gemeiderechnung von 1522 (p. 161). Archiv des Vereins (Neue Foge). Kronstadt.

Wollf, J. (1889). Materialien zur Etimologie Siebenbürgische Ortsnamen (pp. 34-35). Korespondenzblatt des Vereins für Siebenbürghische Landeskündes. Hermmanstadt.

Zimmermann, W. (1990). Urkundenbuch zur Geschichte der Deutschen in siebenbürgens, I. Munchen (Printed in Germnay). 